\title{
A METHOD FOR THE PREPARATION OF CORCHOROSIDE A
}

\author{
R. U. Umarova, V. A. Maslennikova, and N. K. Abubakirov
}

Khimiya Prirodnykh Soedinenii, Vol. 6, No. 1, p. 140, 1970

UDC 615.711 .5

Corchoroside $\mathrm{A}$ is a preparation used in the treatment of cardiovascular insufficiency [1]. Several methods for the isolation of this glycoside directly from the seeds of Corchorus (jute) $[2,3]$ by the hydrolysis of the main glycoside of jute, olitoriside [4], and also from various species of Erysimum [5-7] have been described.

We have developed an enzymatic method for obtaining corchoroside A from residues from the preparation of olitoriside.

To prepare the solution containing the hydrolyzing enzymes, $1 \mathrm{~kg}$ of ground jute seeds was covered with $4 l$ of water cooled to $5^{\circ} \mathrm{C}$, and was kept at $5-10^{\circ} \mathrm{C}$ for $2 \mathrm{hr}$, and then the viscous aqueous solution was centrifuged. After the isolation of the olitoriside, $200 \mathrm{~g}$ (calculated to dry weight) of the noncrystallizing viscous residue was dissolved in $20 l$ of water, and the solution was mixed with $10 \mathrm{ml}$ of toluene and $3 l$ of enzyme solution. The mixture was kept in a thermostat at $35-36^{\circ} \mathrm{C}$ for $48-72 \mathrm{hr}$. Then the solution was concentrated in vacuum at $45-50^{\circ} \mathrm{C}$ to a volume of $3 l$. The concentrate was extracted with chloroform $(5 \times 3 \mathrm{l})$. The chloroformic extract was evaporated to dryness giving $62 \mathrm{~g}$ of a yellowish powder. This was dissolved in $250 \mathrm{ml}$ of $50 \%$ methanol, and the solution was filtered through $60-70$ $\mathrm{g}$ of alumina (activity grade II) in a column with a diameter of $20 \mathrm{~mm}$.

Then the column was washed with $100 \mathrm{ml}$ of $50 \%$ methanol. The combined methanolic solution was left to crystallize for $20-24 \mathrm{hr}$. The yield of corchoroside A (mp 163-165 $\mathrm{C}$ ) was $20 \%$ of the weight of the dry substances of the mother solution.

\section{RE FERE NCES}

1. A. D. Turova, L. I. Leskov, L. N. Sokolova, and L. M. Loshkarev, USSR patent no. 214029, 1968; Izobr., prom. obraz, , tov. znaki, no. 11, 70, 1968.

2. M. Frerejacque and M. Durgeat, C. r. , 238, 507, 1954.

3. W. Kreis, Ch. Tamm, and T. Reichstein, Helv. Chim. Acta, 40, 593, 1957.

4. N. K. Abubakirov, V. A. Maslennikova, and M. B. Gorovits, ZhOKh, 28, 2279, 1958; 29, $1235,1959$.

5. Z. Kowalewski, H. Jäger, O. Schindler, and T. Reichstein, Helv. Chim. Acta, 43, 957, $1280,1960$.

6. N. P. Maksyutina, DAN SSSR, 150, 180, 1963.

7. M. Lukazhevskii, B. Borkovskii, Z. Kovalevskii, and A. Ozarovskii, USSR patent no. 200120, 1967; Izobr., prom. obraz., tov. znaki, no. 16, 84, 1967.

30 September 1969

Institute of the Chemistry of Plant Substances, AS UzSSR 